\title{
Are we conscious of isoprene emissions from our poplar plantations?
}

\author{
Vibha Singhal*, Dinesh Jinger and Jyotirmoy Ghosh
}

The growing energy demand and increasing pollution due to conventional energy sources prompted the concept of bioenergy plantations, which are considered as carbon neutral. The area under bioenergy plantations is increasing rapidly to meet economical and ecological societal needs. Poplar is one of the most important sources of green energy amongst all species. It is widely cultivated as a bioenergy crop due to its fast growth, short rotation and carbon neutrality. However, one of the major aspects that we must consider is that it is a strong emitter of isoprene which can alter ozone flux in the atmosphere. Owing to its extremely reactive nature, isoprene may substantially influence the tropospheric composition by affecting its oxidative capacity with serious impact on air health, global warming, ecological functions and thus human life. We should assess isoprene emissions from existing poplar plantations and the expected increase in isoprene load with future expansion of poplar plantations in India, to know their long-term effect on atmospheric chemistry and climate change. This will help in deciding whether we should further promote poplar plantations, or look for suitable alternative non-/low-emitting species for bioenergy plantations.

Keywords: Bioenergy plantations, global warming, isoprene, ozone, poplar.

INCREASING pollution, deficit resources of fossil fuels and issues of energy security paved the way for the exploration of green energy sources. Use of woody biomass is increasing in India and all over the world. Amongst all green energy sources, poplar has emerged as the most potential source of bioenergy. Poplar, being a fast-growing and short-rotation crop, is suitable and highly productive for energy plantations. It is being extensively used in short-rotation bioenergy plantations for the production of cellulose worldwide. Such energy plantations of poplar are common in India and China ${ }^{1,2}$. Poplar as a source of bioenergy is a renewable substitute to fossil fuels ${ }^{3}$. The green sources of energy are carbon neutral and possess carbon sequestration potential. Therefore, the attraction of bioenergy plantations is not limited to economic interests alone, but these energy sources also have tremendous potential to mitigate climate change and global warming ${ }^{4}$. However, one facet of the bioenergy plantations has not been given due attention which certainly impacts their environment-friendly status. This aspect is the release of BVOC (biogenic volatile organic compounds) by vegetation, particularly the chosen bioenergy trees. Vegetation-originated emission of VOCs

\footnotetext{
Vibha Singhal is in the ICAR-Indian Institute of Soil and Water Conservation, Dehradun 248 195, India; Dinesh Jinger is in the ICARIndian Institute of Soil and Water Conservation, Research Centre, Vasad, Anand 388 306, India; Jyotirmoy Ghosh is in the ICAR-Indian Institute of Natural Resins and Gums, Namkum 834 010, India.

*For correspondence. (e-mail: singhalvibha76@gmail.com)
}

has been estimated to be ten times higher than those released by anthropogenic sources on the global basis ${ }^{5}$. Isoprenoid is one of the most abundant and significant groups of BVOCs. Isoprene, a chemical constituent of the isoprenoid group, represents about $50 \%$ of the global BVOCs emission. It produces a diversity of compounds on reacting with $\mathrm{OH}$ and $\mathrm{NO}_{x}$ through a chain of reactions. These compounds are carbon monoxide, ozone, organic acids, nitrates, peroxyacetyl nitrate and aerosols ${ }^{6}$. Most of the tree species planted in the bioenergy plantation (poplar, willow, eucalyptus and oil palm) across the world are strong emitters of isoprene. Green sources of bioenergy are considered as carbon neutral, but isoprene emission from bioenergy trees may have a greater impact than $\mathrm{CO}_{2}$ on atmospheric composition. Poplar plantations are expanding rapidly for production of biomass, which would enhance tropospheric ozone by increased isoprene emission, detrimental to ecosystem and human health.

\section{International and national status of poplar}

The poplar cover under plantations was estimated to be 31.4 million ha in 2016 across the world ${ }^{7}$. Different proportions of global area under poplar plantations serve different purposes, such as $58 \%$ area is managed for multifarious uses, $30 \%$ for procurement of wood, $9 \%$ for environmental health and management, and rest 3\% for meeting the energy needs in terms of fuelwood. Canada recorded the highest area under poplar $(69 \%$ of the global 
poplar area) followed by China (27\%). France has 0.2 million ha under poplar, whereas USA, Turkey, Spain and Iran each have 0.1 million ha poplar plantations. In agroforestry systems, poplar and willow together constitute 6.3 million ha area, of which maximum is occupied by poplar $(95 \%)$. Mixed plantation of poplar and willow contribute to $4 \%$, whereas only $1 \%$ area is under willows ${ }^{7}$.

India has $32.57 \mathrm{~m}$ ha area under forest plantations, which constitutes $17 \%$ of the total plantation area in the world. The country boasts of having the second largest plantation area in the world, followed by China. Poplar and eucalyptus are the major species in the forest plantations in India along with other species such as acacia, silver oak and rubber wood ${ }^{8}$. The National Poplar Commission, quoting the Forest Survey of India (FSI), has reported 317,800 ha area under poplar in the country (includes area 270,000 ha under Populus deltoides in agrforestry plantations) $)^{9}$.

\section{What is isoprene?}

The simplest form of isoprenoid is isoprene, which is chemically 2-methyl-1,3-butadiene. Most of the trees grown in bioenergy plantations like poplar and willow are strong emitters of isoprene. The share of woody plants in total global isoprene emission to the atmosphere is $75 \%$. Isoprene is one of the most abundant VOCs emitted by biogenic sources. Approximately $0.5-0.6 \mathrm{Pg} \mathrm{C}$ per annum is released as isoprene on the global basis, constituting half of the total BVOCs, one third of non-methane hydrocarbon release ${ }^{5,10}$ and is nearly similar to methane flux to the atmosphere ${ }^{11}$. Biosynthesis of isoprene takes place in chloroplasts through the methylerythritol 4-phosphate (MEP) pathway, where dimethylallyl diphosphate (DMADP) changes to isoprene with the help of an enzyme known as isoprene synthase. Depending on the concentration of nitrous oxide, it can alter ozone fluxes (increase/decrease) in the atmosphere by oxidation ${ }^{12}$. Many researchers have recently supported the fact that VOC release from vegetation may significantly alter troposphere composition by the formation of ozone and secondary air pollutants ${ }^{13}$. The chemical compounds of the isoprenoids group, especially isoprene, feed the NO$\mathrm{NO}_{2}-\mathrm{O}_{3}$ cycle, thus resulting in the formation or degradation of ozone in the troposphere ${ }^{14}$. Geng et al. ${ }^{15}$ observed that the BVOC release from prominent forest types located to the south of Shanghai, China, enhanced ozone production $\left(6-8 \mathrm{pb} \mathrm{h}^{-1}\right)$ in the city, primarily due to the carbonyl formation as a result of constant isoprene oxidation in the forest air. The substantial formation of ozone due to isoprene (12-14\%) occurs when the $\mathrm{VOC} / \mathrm{NO}_{x}$ ratio lies between 4 and 12, according to studies conducted in Rio de Janeiro ${ }^{16}$. On the basis of output from MEGAN (Model of Emissions of Gases and Aerosols from $\mathrm{Na}$ - ture), Pike et al. ${ }^{17}$ showed that isoprene emission peak in the Northern Hemisphere in July corresponds to increase in ozone owing to the simultaneous release of isoprene and $\mathrm{NO}_{x}$ from biogenic and anthropogenic sources respectively. Isoprene scavenges the $\mathrm{OH}$ radicals and alters the atmospheric composition by affecting its oxidative capacity, and thus the lifespan of atmospheric methane, condensation, nucleation or formation of secondary organic aerosols (SOAs) ${ }^{18}$. Claeys et al. ${ }^{19}$ provided the first field evidence for the contribution of isoprene to ambient organic aerosol formation through oxidation in the Amazonian rainforest. They showed the presence of 2methyltetrols compounds in aerosols having the same carbon skeleton as isoprene. Further studies strongly suggested that isoprene oxidation results in the production of methyltetrols, thus indicating that isoprene is an important precursor of SOAs. A growing body of literature subsequently indicated that oxidation of isoprene significantly influences SOA production in the troposphere ${ }^{20-23}$. Even if the production is small (say $1 \%$ ), isoprene can substantially enhance the total atmospheric POM (particulate organic matter) to a greater extent (e.g. $6 \mathrm{Tg} \mathrm{yr}^{-1}$ ) due to large global emission and its high reactivity. Pike et al. $^{17}$ suggested that isoprene may cause $22.5 \%$ increase in the lifespan of tropospheric methane by acting as a scavenger for $\mathrm{OH}$ radicals. Thus isoprene emission can seriously impact atmospheric pollution, climate change and global warming.

\section{BVOC emission in poplar}

All species of poplar studied till date are isoprene emitters. They emit isoprene in response to biotic (infestation by microorganisms and herbivores) and abiotic (heat, drought, oxidative stress, etc.) factors. Usually emission of BVOCs varies in their mixing ratios depending upon inducing stimulus and emitting species (Table 1$)^{24-26}$.

\section{Functions of isoprene in plants}

Production of isoprene is expensive for the plants ${ }^{27}$. The utilization of carbon for biosynthesis of isoprene under stress conditions favours the theory that isoprene plays a protective role under environmental stresses. It had been reported that isoprene plays an important role in the protection mechanism of plants against heat and ozone dam$\operatorname{age}^{28,29}$. At high temperatures, synthesis of isoprene in the leaves gets elevated indicating its role against hightemperature episodes. This may be due to the fact that isoprene has low heat capacity compared to water ${ }^{27}$. The role of isoprene is not limited to protection against heat, but extends to the recovery of plants post heat episodes. However, the defence mechanism of plants against heat stress through isoprene emission is still not clearly understood. The most popular theory about the protection 
GENERAL ARTICLES

Table 1. Emission of BVOCs (biogenic volatile organic compounds) in response to stimuli in poplar

\begin{tabular}{lc}
\hline Stress factor & BVOCs emitted \\
\hline Forest tent caterpillars and moth larvae & $\begin{array}{c}\text { A mixture of various monoterpenes and sesquiterpenes }(\beta \text {-ocimene, linalool, } \\
\alpha \text {-farnesene, }(\mathrm{E})-4,8 \text {-dimethyl-1,3,7-nonatriene (DMNT), germacrene D and } \\
\text { caryophyllene })\end{array}$ \\
$\begin{array}{l}\text { Monoterpenes and homoterpenes (mainly } \beta \text {-ocimene, DMNT and linalool) } \\
\text { Ozone stress }\end{array}$ & $\begin{array}{l}\text { Monoterpenes }(\alpha \text { - and } \beta \text {-pinene), homo and sesquiterpenes (ocimenes, DMNT, TMTT, } \\
\text { Pathogenic fungus (Pollacia radiosa) })\end{array}$ \\
\hline
\end{tabular}

mechanism of isoprene is that it stabilizes the thylakoid membrane by interacting with the non-polar components of the membrane due to its hydrophobic nature, thus making them resistant to denaturation ${ }^{27}$. Research conducted in the case of transgenic poplar (non-isoprene emitters) clearly showed the function of isoprene in the protection mechanism against heat stress by net $\mathrm{CO}_{2}$ assimilation and photosynthetic electron transport ${ }^{30,31}$. Many researchers also reported that the antioxidant property of isoprene may possibly be attributed to its potential of quenching reactive oxygen species (ROS) generated under oxidative stress (induced by ozone, salinity, drought and also sunflecks $)^{32,33}$. According to Vickers et $a l .^{33}$, the antioxidant characteristic of isoprene is due to its double bond, an attribute of all higher compounds of the isoprenoid group which show antioxidant nature. Isoprene synthesis performs a regulatory function in the MEP (methyl-Derythritol-4-phosphate) pathway, which is primarily responsible for the production of important isoprenoids in plants. During oxidative stress caused by drought, biosynthesis of isoprene limits the build-up of DMADP by biochemical feedback down regulation of the MEP pathway utilizing the excessive reducing power ${ }^{34}$. Recent work has also shown the direct and indirect roles of isoprene in the protection mechanism against herbivore infestation. Laothawornkitkul et al. ${ }^{35}$ reported that isoprene emission discourages feeding of Manduca sexta caterpillars in transgenic tobacco (Nicotiana tabacum cv. Samsun). It protects the plant from generalist pests ${ }^{36,37}$; thus alien species which lack specialist parasites may get benefit being emitters ${ }^{35,38}$.

\section{Discussion and conclusion}

There is expected increase in area under bioenergy plantation globally through afforestation on marginal land and apportioned agricultural lands to fulfil the demand for energy. Wiedinmyer et al. ${ }^{39}$ simulated the worldwide changes in isoprene release due to anticipated land-cover changes in future through model-based projections. They estimated $889 \mathrm{Tg} \mathrm{yr}^{-1}$ of isoprene emission on the global basis using future temperature and land-use variables for predictions. Land-use changes due to anthropogenic fac- tors such as population pressure, conversion of natural forests to plantations and modernization can enhance isoprene load, consequently increasing tropospheric ozone and photochemical air pollutants at the regional level. With promotion of bioenergy plantations and short rotation crops worldwide, these effects will be serious, particularly at a regional scale ${ }^{40}$. For example, large-scale conversion of land in China for raising tree plantations (e.g. eucalyptus and rubber trees) for commercial use had increased isoprene loads to a great extent ${ }^{41}$. Fowler et $a l .^{42}$ reported three times higher biosynthesis of isoprene due to expansion of oil palm plantation on $27 \mathrm{M}$ ha land than native crops in Southeast Asia, causing 11\% increase in surface ozone. Ashworth et al. ${ }^{43,44}$ predicted that expansion of 72 Mha area under poplar to fulfil the anticipated requirement of biomass as a non-conventional source of energy in the European Union, will lead to $39 \%$ increase in isoprene emissions. Similarly, $\mathrm{O}_{2} / \mathrm{O}_{3}$ ratios are anticipated to be high up to $2.26 \mathrm{ppb}$ due to increased isoprene load following the expansion of short-rotation crops, mainly poplar in the temperate Northern Hemisphere (Eurasia, North America, and China) ${ }^{43,45}$. Results from past simulation studies suggested that higher rate of isoprene emission due to increase in area under poplarbased bioenergy plantations would substantially alter ozone level in the atmosphere, threatening ecosystem processes and human life. In India also, the area under bioenergy plantations is expected to increase at a large scale to fulfil the huge demands of industries. Pulpwood industries in India promoted bioenergy plantations through farm forestry under several schemes to fullfil the requirement of raw material. Area under bioenergy plantations reached nearly 343,000 ha by 2005 in a period of 16 years as a result of serious efforts made by the paper industries. At present, the target of paper industries is to expand plantations in an area of 65,000 ha per annum. However, to fulfill the additional need of 3 million tonnes per annum of pulpwood, 50,000 ha more area of bioenergy plantations is required at the prevailing productivity range. Therefore, the target is to plant 115,000 ha under poplar and eucalyptus every year to meet the demand of pulpwood $^{46}$. However we lack information on isoprene estimation through such massive plantation drives in the country. Isoprene emissions due to poplar plantation in 
India should be assessed, and the impact of isoprene load on air pollution and global warming must be analysed. Future planning of expanding area under bioenergy plantations through poplar should be based on prediction of isoprene emissions by simulation studies, and its impact on regional air health, atmospheric chemistry and global warming.

\section{Solutions/recommendations}

- Regional studies should be conducted to determine $\mathrm{NO}_{x}$ concentration in a particular area, as isoprene will increase or decrease ozone flux depending on nitrous oxide concentration of that area.

- Poplar germplasm should be screened for isoprene emission to identify low-emitting lines. Research should be carried out on developing low isopreneemitting transgenic poplars through genetic manipulation.

- Other plant species suitable for bioenergy plantations, e.g. Melia dubia should be screened for isoprene emissions.

- Native species should be preferred for bioenergy planation as it was found that their isoprene biosynthesis/emission rate is lower than co-occurring alien species $^{36}$.

- Local species should be given priority in comparison to hybrids as tree genera characterized by extensive speciation and hybridization were observed to emit isoprene more frequently than their phylogenetically nearest non-speciose genera ${ }^{47}$.

1. International Poplar Commission (IPC), Report of the 21st Session of the International Poplar Commission. Food and Agriculture Organization (FAO), Portland, USA, 2000.

2. IPC, Report of the 22nd Session of the International Poplar Commission. FAO, Santiago, Chile, 2004; http://www.fao.org/forestry/ media/9497/1/0/

3. Vande Walle, I., Van Camp, N., Van de Casteele, L, Verheyen, K. and Lemeur, R., Short-rotation forestry of birch, maple, poplar and willow in Flanders (Belgium) II. Energy production and $\mathrm{CO}_{2}$ emission reduction potential. Biomass Bioenerg., 2007, 31, 276283.

4. Behnke, K. et al., Isoprene emission-free poplars: a chance to reduce the impact from poplar plantations on the atmosphere. New Phytol., 2012, 194, 70-82.

5. Guenther, A., Karl, T., Harley, P., Wiedinmyer, C., Palmer, P. I. and Geron, C., Estimates of global terrestrial isoprene emissions using MEGAN (Model of Emissions of Gases and Aerosols from Nature). Atmos. Chem. Phys., 2006, 6, 3181-3210.

6. Claeys, M. et al., Formation of secondary organic aerosols through photooxidation of isoprene. Science, 2004, 303, 11731176.

7. International Poplar Commission, Poplars and other fast-growing trees - renewable resources for future green economies. Working Paper IPC/15, FAO, Rome, Italy, 2016.

8. MoEF, India Forestry Outlook Study. Ministry of Environment and Forests, Government of India (GoI), FAO Working Paper Series No. apfsos ii/wp/2009/06, Bangkok, 2009.
9. National Poplar Commission, India - country report on poplars and willows. Indian Council of Forestry Research and Education, Dehradun, 2012.

10. Guenther, A. B., Jiang, X., Heald, C. L., Sakulyanontvittaya, T., Duhl, T., Emmons, L. K. and Wang, X., The Model of Emissions of Gases and Aerosols from Nature version 2.1 (MEGAN2.1): an extended and updated framework for modeling biogenic emissions. Geosci. Model Dev., 2012, 6, 1471-1492; doi:10.5194/gmd5-1471-2012.

11. Wang, K. Y. and Shallcross, D. E., Modelling terrestrial biogenic isoprene fluxes and their potential impact on global chemical species using a coupled LSM-CTM model. Atmos. Environ., 2000, 34, 2909-2925.

12. Zeng, G., Pyle, J. A. and Young, P. J., Impact of climate change on tropospheric ozone and its global budgets. Atmos. Chem. Phys., 2008, 8, 369-387.

13. Harley, R. A. and Cass, G. R., Modeling the atmospheric concentrations of individual volatile organic compounds. Atmos. Environ., 1995, 29, 905-922; doi:10.1016/1352-2310(94)00287-U

14. Jardine, K. J. et al., Within-plant isoprene oxidation confirmed by direct emissions of oxidation products methyl vinyl ketone and methacrolein. Global Change Biol., 2012, 18, 973-984.

15. Geng, F. H., Xuexi, T., Guenther, A., Guohui, L., Junji, C. and Hartly, P., Effect of isoprene emissions from major forests on ozone formation in the city of Shanghai, China. Atmos. Chem. Phys., 2011, 11, 10449-10459; 10.5194/acp-11-10449-2011.

16. Da Silva, C. M., Corrêa, S. M. and Arbilla, G., Isoprene emissions and ozone formation in urban conditions: a case study in the city of Rio de Janeiro. Bull. Environ. Contamin. Toxicol., 2017, 100(1), 184-188; doi:10.1007/s00128-017-2248-6

17. Pike, R. C. and Young, P. J., How plants can influence tropospheric chemistry: the role of isoprene emissions from the biosphere. Weather, 2009, 64(12), 332-336.

18. Ying, Q., Li, J. and Kota, S. H., Significant contributions of isoprene to summertime secondary organic aerosol in Eastern United States. Environ. Sci. Technol., 2015, 49, 7834-7842; 10.1021/acs.est.5b02514.

19. Claeys, M. et al., Formation of secondary organic aerosols through photooxidation of isoprene. Science, 2004, 303, 11731176.

20. Edney, E. O. et al., Formation of 2-methyl tetrols and 2methylglyceric acid in secondary organic aerosol from laboratory irradiated isoprene/ $\mathrm{NO}_{x} / \mathrm{SO}_{2} /$ air mixtures and their detection in ambient $\mathrm{PM}_{25}$ samples collected in the eastern United States. Atmos. Environ., 2005, 39, 5281-5289.

21. Kroll, J. H., Ng, N. L., Murphy, S. L., Flagen, R. C. and Seinfeld, J. H., Secondary organic aerosol formation from isoprene photooxidation under high- $\mathrm{NO}_{x}$ conditions. Geophys. Res. Lett., 2005, 32, L18808.

22. Kleindienst, T., Lewandowski, M., Offenberg, J., Mohammed, J. and Edward, E., The formation of secondary organic aerosol from the isoprene $+\mathrm{OH}$ reaction in the absence of $\mathrm{NO}_{x}$. Atmos. Chem. Phys., 2009, 9; doi:10.5194/acp-9-6541-2009.

23. Ng, N. L. et al., Contribution of first- versus second-generation products to secondary organic aerosols formed in the oxidation of biogenic hydrocarbons. Environ. Sci. Technol., 2006, 40, 22832297.

24. Blande, J. D., Tiiva, P., Oksanen, E. and Holopainen, J. K., The emission of herbivore induced volatile terpenoids from two hybrid aspen (Populus tremula $\cdot$ tremuloides) clones under ambient and elevated ozone concentrations in the field. Global Change Biol., 2007, 13, 2538-2550.

25. Brilli, F., Ciccioli, P., Frattoni, M., Prestininzi, M., Spanedda, A. F. and Loreto, F., Constitutive and herbivore-induced monoterpenes emitted by Populus euroamericana leaves are key volatiles that orient Chrysomela populi beetles. Plant Cell Environ., 2009, 32, $542-552$. 
26. Behnke, K., Kleist, E., Uerlings, R., Wildt, J., Rennenberg, H. and Schnitzler, J. P., RNAi mediated suppression of isoprene biosynthesis impacts ozone tolerance. Tree Physiol., 2009, 29, 725-736.

27. Sharkey, T. D. and Yeh, S., Isoprene emission from plants. Annu. Rev. Plant Physiol. Plant Mol. Biol., 2001, 52, 407-436.

28. Sharkey, T. D. and Singsaas, E. L., Why plants emit isoprene. Nature, 1995, 374, 769.

29. Loreto, F. and Velikova, V., Isoprene produced by leaves protects the photosynthetic apparatus against ozone damage, quenches ozone products, and reduces lipid peroxidation of cellular membranes. Plant Physiol., 2001, 127, 1781-1787; doi:10.1104/ pp.010497

30. Behnke, K. et al., Transgenic, non-isoprene emitting poplars don't like it hot. Plant J., 2007, 51, 485-499.

31. Behnke, K. et al., RNAi-mediated suppression of isoprene emission in poplar transiently impacts phenolic metabolism under high temperature and high light intensities: a transcriptomic and metabolomic analysis. Plant Mol. Biol., 2010, 74, 61-75.

32. Loreto, F., Mannozzi, M., Maris, C., Nascetti, P., Ferranti, F. and Pasqualini, S., Ozone quenching properties of isoprene and its antioxidant role in plants. Plant Physiol., 2001, 126, 1-8.

33. Vickers, C. E. et al., Isoprene synthesis protects transgenic tobacco plants from oxidative stress. Plant Cell Environ., 2009, 32, 520 531.

34. Banerjee, A., Wu, Y., Banerjee, R., Li, Y., Yan, H. and Sharkey, T. D., Feedback inhibition of deoxy-D-xylulose-5-phosphate synthase regulates the methylerythritol 4-phosphate pathway. J. Biol. Chem., 2013, 288, 16926-16936; doi:10.1074/jbc.M113.464636

35. Laothawornkitkul, J. et al., Isoprene emissions influence herbivore feeding decisions. Plant Cell Environ., 2008, 31, 1410-1415; doi:10.1111/j.1365-3040.2008.01849.x

36. Llusià, J., Penuelas, J., Sardans, J., Owen, S. M. and Niinemets, U., Measurement of volatile terpene emission in 70 dominant vascular plant species in Hawaii: aliens emit more than native. Global Ecol. Biogeogr., 2010, 19, 863-874; doi:10.1111/j.14668238.2010.00557

37. Harrison, S. P. et al., Volatile isoprenoid emission from plastid to planet. New Phytol., 2013, 197, 49-57; doi:10.1111/nph.12021.x

38. Mithofer, A. and Boland, V., Plant defense against herbivores: chemical aspects. Annu. Rev. Plant Biol., 2012, 63, 431-450; doi:10.1146/annurev-arplant-042110-103854
39. Wiedinmyer, C., Tie, X., Guenther, A., Neilson, R. and Granier, C., Future changes in biogenic isoprene emissions: how might they affect regional and global atmospheric chemistry? Earth Interact., 2006, 10(3), 1-19; EI174; doi:10.1175/EI174.1.

40. Sharkey, T. D. and Monson, R. K., The future of isoprene emission from leaves, canopies and landscapes. Plant Cell Environ., 2014, 37, 1727-1740.

41. Geron, C. et al., Volatile organic compounds from vegetation in southern Yunnan Province, China: emission rates and some potential regional implications. Atmos. Environ., 2006, 40, 17591773.

42. Fowler, D. et al., Effects of land use on surface-atmosphere exchanges of trace gases and energy in Borneo: comparing fluxes over oil palm plantations and a rainforest. Philos. Trans. R. Soc. Lond. Biol. Sci., 2011, 366(1582), 3196-3209; doi:10.1098/ rstb.2011.0055, 2011

43. Ashworth, K., Folberth, G., Hewitt, C. N. and Wild, O., Impacts of near-future cultivation of biofuel feed stocks on atmospheric composition and local air quality. Atmos. Chem. Phys., 2012, 12, 919-939.

44. Ashworth, K., Wild, O. and Hewitt, C. N., Impacts of biofuel cultivation on mortality and crop yields. Nature Climate Change, 2013, 3, 492-496; doi:10.1038/Nclimate1788.

45. Hardacre, C. J., Palmer, P. I., Baumanns, K., Rounsevell, M. and Murray-Rust, D., Probabilistic estimation of future emissions of isoprene and surface oxidant chemistry associated with land use change in response to growing food needs. Atmos. Chem. Phys., 2013, 13, 5451-5472; doi:10.5194/acp-13-5451-2013

46. MoEF, India Outlook Study, Asia-Pacific Forestry Sector Outlook Study II, Country report. Ministry of Environment \& Forests, GoI, 2020.

47. Dani, S. K. G., Jamie, I. M., Prentice, I. C. and Atwell, B. J., Evolution of isoprene emission capacity in plants. Trends Plant Sci., 2014, 19, 439-445; doi:10.1016/j.tplants.2014.01.009.

Received 8 June 2020; revised accepted 17 November 2020

doi: $10.18520 / \mathrm{cs} / \mathrm{v} 120 / \mathrm{i3} / 479-483$ 